Tropical Journal of Pharmaceutical Research, December 2002; 1 (2): 91-98

(C) Pharmacotherapy Group,

Faculty of Pharmacy, University of Benin,

Benin City, Nigeria.

All rights reserved.

Available online at http://www.tjpr.freehosting.net

Research Article

\title{
Studies on the Genotoxic and Mutagenic Potentials of Mefloquine
}

\author{
John O Akerele ${ }^{\dagger}$ and Emmanuel E Obaseiki-Ebor \\ Department of Pharmaceutical Microbiology, University of Benin, PMB 1154, Benin City, Nigeria
}

\begin{abstract}
Purpose: The detection of mefloquine mutagenicity has not been achieved by the use of Salmonella typhimurium his TA1535, TA1537 as tester strains. With the introduction of improved and more sensitive strains, it is of interest to evaluate the current mutagenic and genotoxic status of the drug. This study presents data on the in-vitro mutagenic and genotoxic potentials of mefloquine hydrochloride clinically used as an antimalarial agent.

Method: The mutagenicity potentials was investigated in the Escherichia coli $W P_{2}$ trp and $W P_{2}$ uvrA trp tester strains containing the plasmids, pEB017 and pKM101, and the Salmonella typhimurium TA97 containing pKM101. The genotoxicity potential was determined using the microscreen phage-induction assay.

Results: The presence of plasmids pEBO17 and pKM101 enhanced the detection of mutagenicity of mefloquine. Microsomal-activated mefloquine unequivocally elicited base-pair substitution mutagenicity. The genotoxicity test indicated that mefloquine was generally not genotoxic but was of the same potential mutagenicity as chloroquine phosphate.

Conclusion: Melfloquine hydrochloride exhibits base pair substitution mutagenesis, but not potentially genotoxic, even though it showed concentration dependent cytotoxicity. Its use as a last line antimalarial agent should still be encouraged.
\end{abstract}

Key Words: Base-pair substitution, genotoxicity, mefloquine hydrochloride, mutagenicity, $R$ plasmid $p E B 017$

†To whom correspondence should be addressed: E-mail: akerelej@uniben.edu or akerelej@yahoo.com 


\section{JO Akerele \& EE Obaseiki-Ebor}

\section{Introduction}

The use of Salmonella typhimurium his TA1535, TA1537 etc. strains ${ }^{1,2}$ introduced a novel epoch in the rapid detection of mutagenic or carcinogenic chemical compounds. These strains, however, would not detect mefloquine - a quinoline-methanol antimalarial agent developed against chloroquine resistant Plasmodium sp) to be mutagenic. With the introduction of the improved and more sensitive Salmonella typhimurium his strains such as TA97, TA98, TA100, etc ${ }^{3,4}$ and other bacterial strains and bacteriophages, using more sensitive assay procedures to detect environmental genotoxic agents, it became necessary to reassess the mutagenicity and genotoxicity status of mefloquine. Mefloquine is one of the last line therapeutic drugs recently developed against the increasingly prevalent chloroquine - resistant Plasmodium falciparium parasite, a causative agent of chloroquine - resistant malarial fever.

The improved Salmonella typhimurium his TA97 strain is known to be very sensitive for the detection of frameshift mutagens ${ }^{4}$. Escherichia coli trp $\mathrm{WP}_{2}$ tester strains also detect base-pair substitution mutagenesis ${ }^{5,6}$. Salmonella typhimurium his TA97 was proposed as a replacement for TA1537 ${ }^{3,4}$ and it also contained the plasmid pKM101 which had been reported to enhance errorprone DNA repair and mutagenesis ${ }^{1,7}$. A novel plasmid pEB017 ${ }^{8}$ has also been reported to enhance bacterial mutagenesis ${ }^{9}$ which was incorporated into the $E$. coli trp $\mathrm{WP}_{2}$ tester strains as $\mathrm{WP}_{2}$ trp (pEB017). The suitably modified protocol of the highly sensitive microscreen prophage induction assay earlier described ${ }^{10,11}$ was adapted for determining the genotoxicity potential of mefloquine. Microscreen phage induction assays detects potential genotoxins, mutagens and carcinogen which are as sensitive as the mutagenicity test of Ames et $\mathrm{al}^{2}$. Activation of the compound through their prophage inducing activity in bacgteria has correlated well with their carcinogenic and genotoxic activities ${ }^{12}$. It measures the formation of prophage from a complex molecular events through the induction of the 'SOS' molecular response - a cellular reaction to DNA damage. The present study is designed to ascertain the mutagenicity and genotoxicity status of mefloquine using Salmonella typhimurium his TA97 and E. coli trp $\mathrm{WP}_{2}$ strains.

\section{Experimental}

\section{Bacterial Strains}

The Salmonella typhimurium his TA97 strains contains R-plasmid pKM $101^{3,4}$ and mediates frameshift mutagenesis on reversion from $\mathrm{His}^{-}$to $\mathrm{His}^{+}$by a putative mutagen. The Escherichia coli $\mathrm{WP}_{2}$ strains were $\mathrm{WP}_{2}$ trp $u v r A^{5,6}, \mathrm{WP}_{2}$ (pKM101) trp ${ }^{13}$ and $\mathrm{WP}_{2}$ (pEB017) trp ${ }^{8}$. These E. coli strains respond to base-pair substitution mutagenesis by reverting from Trp auxotrophs to $\operatorname{Trp}^{+}$prototrophs. Bacteriophage - lambda lysogen E. coli $\mathrm{WP}_{2} \mathrm{~S}$ (lambda) $\mathrm{F}^{-}$. trp and the indicator strains $E$. coli $\mathrm{TH}-008$ (streptomycin resistant) were provided by Dr. Toby $\mathrm{E}$. Rossman of the Institute of Environmental Medicine New York. Purified single colony isolates of all the tester strains were subcultured on nutrient agar slants and stored at $4^{\circ} \mathrm{C}$.

\section{Media}

Nutrient broth No. 2 (Oxoid); nutrient agar (Oxoid); agar No. 1 (Oxoid); Davis and Mingioli (DM) $1950^{14}$ salts solution; VogelBonner minimal medium supplemented with $0.2 \%{ }^{w} \bullet$ v glucose; Salmonella mutagenicity test plates were prepared as directed ${ }^{4}$. $E$. coli trp mutagenicity test plates were prepared with and without the inclusion of 20 $\mathrm{mg} / \mathrm{ml}$ tryptophan. Tryptone medium $(10 \mathrm{~g}$ of Bactone tryptone, $6 \mathrm{~g}$ of $\mathrm{NaCl}$ and $12 \mathrm{~g}$ of Bacto agar per litre of distilled water). Streptomycin $(100 \mathrm{mg} / \mathrm{ml})$ was added to the tryptone medium to select against the lysogen. 


\section{JO Akerele \& EE Obaseiki-Ebor}

\section{Drugs and biochemical}

A stock solution $(1 \mathrm{mg} / \mathrm{ml})$ of mefloquine hydrochloride (obtained from Walter Reed Army Institute of Research, Washington, D.C., USA) was prepared and sterilised by filtration with bacteria proof membrane filters (Millipore, USA) and stored in an amber coloured bottle. Chloroquine phosphate, nalidixic acid (sodium salt), 2-nitrofluorene (used as positive controls to induce prophage) and reduced nicotinamide adenine dinucleolide phosphate (NADPH) type I) were obtained from Sigma-Aldrich (Gillingham-Dorset,UK).

\section{Animals}

Albino (Sprague-Dawley) rats weighing 130$200 \mathrm{~g}$ were injected peritoneally with phenobarbitone sodium $(50 \mathrm{mg} / \mathrm{kg})$ for seven consecutive days before they were killed. The livers of the rats were aseptically removed and pooled in a beaker containing TrisHCl $(\mathrm{pH} 7.5)$ at approximately $3 \mathrm{ml} / \mathrm{g}$ wet liver as earlier described ${ }^{15}$.

Preparation of liver homogenate fraction (S9)

The procedure of Ames et al. ${ }^{2}$ was modified where necessary. The liver lobes were minced with sterile scissors and manually homogenized in a mortar and pestle that had been oven-sterilised and cooled to $4^{\circ} \mathrm{C}$. The homogenate was centrifuged at $9000 \mathrm{xg}$ for $20 \mathrm{~min}$ in an high speed 18 centrifuge (MSE, Sanyo, UK) at $4^{\circ} \mathrm{C}$. The supernatant was carefully decanted into a sterile universal bottle and kept on ice. The liver extract (S-9) was immediately used for the mutagenicity tests after determining its protein concentration. The protein concentration was estimated using the method of Lowry et al. ${ }^{16}$ with bovine serum albumin as standard.

\section{Determination of minimum inhibitory concentration (MIC) of mefloquine}

The MIC of mefloquine against the test bacterial strains was determined by the agar dilution protocol as previously described ${ }^{13}$.

\section{Mutagenicity testing}

Mutatenicity testing was carried out by the plate incorporation method with and without activation using the method of Brusick et al. $^{17}$ was suitably modified as previously validated $^{15}$. Sub-inhibitory concentrations of mefloquine $(2.5$ and $5 \mu \mathrm{g} / \mathrm{ml}$ ) were added to tubes containing $2.5 \mathrm{ml}$ of molten overlay agar $\left(0.7 \% \mathrm{w} / \mathrm{v}\right.$ agar-agar) held at $45^{\circ} \mathrm{C}$. An aliquot of $0.1 \mathrm{ml}$ of undiluted, washed test culture were added to the tubes. The contents of the tubes were gently mixed and immediately poured onto the top of the prepared mutagenicity test agar plate and allowed to solidify. Positive control plates (containing $20 \mu \mathrm{g} / \mathrm{ml}$ tryptophan or histidine and no test agent) and negative control plates were also prepared. All plates were incubated at $37^{\circ} \mathrm{C}$ for $48 \mathrm{hr}$ and the mean number of colonies growing per plate in triplicate experiments were recorded.

Activation was achieved in the plate incorporation method with NADPH and the enzyme preparation (S-9 mix). In this case, a sub-inhibitory concentration of mefloquine $(0.1 \mathrm{ml}$ of the undiluted test culture), $0.1 \mathrm{ml}$ of NADPH $10 \mathrm{mg} / \mathrm{ml}$ stock solutions, and 0.5 $\mathrm{ml}$ of the $\mathrm{S}-9$ extract $(3.13 \mathrm{ml} / \mathrm{ml}$ protein) at $4^{\circ} \mathrm{C}$ were mixed in sterile universal bottles and incubated at room temperature for 15 min. This mixture was added to $2.5 \mathrm{ml}$ molten overlay agar $(0.7 \%)$ held at $45^{\circ} \mathrm{C}$ and immediately poured on the top of the prepared mutagenicity test plates and the respective control plates allowed to solidify followed by the subsequent incubation at $37^{\circ}$ C for $48 \mathrm{hr}$. 


\section{JO Akerele \& EE Obaseiki-Ebor}

\section{Tubes fluctuation test}

The method of Green et al. ${ }^{18}$ was suitably modified as earlier validated ${ }^{15}$. A fresh overnight washed test culture in $10 \mathrm{ml}$ Davis \& Mingioli liquid medium appropriately supplemented with either $20 \mu \mathrm{g} / \mathrm{ml}$ of histidine or tryptophan and $200 \mu \mathrm{g} / \mathrm{ml}$ of glucose was grown to log phase, harvested and washed free of the histidine or tryptophan supplement. The resuspended culture, $0.4 \mathrm{ml}\left(1 \times 10^{9} \mathrm{cfu} / \mathrm{ml}\right)$ in $10 \mathrm{ml}$ sterile distilled water was inoculated into $400 \mathrm{ml}$ Davis \& Mingioli basal salts containing glucose $(200 \mu \mathrm{g} / \mathrm{ml})$, biotin $(5 \mu \mathrm{g} / \mathrm{ml})$ and bromocresol purple indicator $12 \mu \mathrm{g} / \mathrm{ml}$. The contents were thoroughly mixed and aseptically divided into 4 portions of $200 \mathrm{ml}$ as follows: $100 \mathrm{ml}$ aliquot containing test concentrations of mefloquine (in duplicate); $100 \mathrm{ml}$ aliquot containing additional concentrations of histidine or tryptophan (20 $\mu \mathrm{g} / \mathrm{ml}) ; 100 \mathrm{ml}$ aliquot containing no histidine, tryptophan or mefloquine. The contents of each flask were aseptically dispensed in $2 \mathrm{ml}$ aliquot to 50 small sterile test tubes and incubated at $37^{\circ} \mathrm{C}$. As from $72 \mathrm{hr}$ of incubation, the tubes containing $\mathrm{His}^{+}$ or $\mathrm{Trp}^{+}$revertants were turbid changing their colouration from purple to yellow and were recorded. Each duplicate test concentration of mefloquine was determined on at least two occasions.

For tubes fluctuation test with S-9 activation, the broth was supplemented minimal salts aliquot (above) contained, in addition to the test culture, $0.25 \mathrm{ml}$ of the S-9 extract $(3.13$ $\mathrm{mg} / \mathrm{ml})$, protein $(0.5 \mathrm{ml}$ of $10 \mathrm{mg} / \mathrm{l} \mathrm{NADPH})$ and the appropriate concentration of mefloquine.

\section{Prophage Induction Assay}

The microscreen prophage induction assay was performed as described by DeMarini et al. ${ }^{11}$. Sterile plastic 96-well microlitre plates (Corning, New York, USA) were used for the microsuspension assay. Briefly, the first well in a dilution series of the 96 well microlitre plates had $250 \mu \mathrm{l}$ of supplemented VogelBonner minimal salts containing $0.2 \%$ glucose and $20 \mu \mathrm{g} / \mathrm{ml}$ of tryptophan and 50 $\mu \mathrm{l}$ of either the mefloquine $(100 \mu \mathrm{g} / \mathrm{ml})$ or the control i.e., nalidixic acid and/or 2nitrofluorene. The remaining wells had 150 $\mu l$ of the medium with subsequent two-fold serial dilution of each well content down the column of each plate. Each well was inoculated with $75 \mu \mathrm{l}$ (about $2 \times 10^{5}$ cells) of a resuspended log-phase culture of $W P_{2} s^{11}$. In case of microsomal activation of the mefloquine, $25 \mu \mathrm{l}$ of the prepared S-9 mix $100 \mu \mathrm{l}$ of NADPH $(10 \mathrm{mg} / \mathrm{ml})$ were added to each well. Contents of each microlitre plate were mixed using a minimixer (Fisson plc, Loughborougb, UK), the lid was placed tightly on the plate, and the plates were incubated overnight at $30^{\circ} \mathrm{C}$.

\section{Assay for plaque formation}

After incubation, the wells were scored for turbidity. Turbid wells indicated cell growth and clear wells indicated genotoxicity and/or inhibition of cell growth. The concentration of the lambda phage was determined by sampling the first three turbid wells. Whenever there was a clear well, samples were obtained from the first three wells adjacent to the last clear well. A sample (50 $\mu$ l) from a well was diluted in $2.5 \mathrm{ml}$ of the supplemented minimal medium and $100 \mu \mathrm{l}$ of the dilution was added to about $2.5 \mathrm{ml}$ of top agar $\left(0.6 \%\right.$ Bacto agar and $\left.10 \mathrm{mM} \mathrm{MgSO}_{4}\right)$ along with $200 \mu \mathrm{l}$ of log-phase indicator cells (TH-008), which had been grown in Oxoid No. 2 nutrient broth. The content of each tube was poured onto bottom agar made of tryptone medium. The plates were incubated overnight at $37^{\circ} \mathrm{C}$ and plaques were counted. The number of plaques from a dilution series of the microlitre plate that did not contain any test compound (control) was also determined.

\section{Analysis of data}

Scoring by Houk and DeMarini ${ }^{10,}{ }^{11}$ and DeMarini et al. ${ }^{19}$ were adopted. Induced 


\section{JO Akerele \& EE Obaseiki-Ebor}

plaque forming unit per plate (i.e., PFU/plate that reached the upper limit of the $99 \%$ confidence interval) represents an approximate three-fold increase over the background (tubes without any test compound or control). A dose-related increase of induced PFU/plate that reached or exceeded a three-fold increase in PFU/plate was considered a positive response. If a compound's response reached or exceeded the fold increase at only one dose, the result was scored as a weak positive.

\section{Results}

The plate incorporation tests showed that the repair-deficient strain, $W_{2}$ uvrA responded positively to activated mefloquine when compared with the negative response with $\mathrm{WP}_{2}$ trp, which are DNA-repair proficient. Strains TA97, $W_{2}$ trp (pEB017), $W_{2}$ (pKM101) - all bearing mutator $R$-plasmids responded positively to activated mefloquine mutagenicity (Table 1). It would also be seen from the tube fluctuation tests that microsomally activated mefloquine elicited base-pair substitution mutation with the tester strains bearing mutator $R$-plasmids (Table 2). The activated mefloquine elicited prophage induction to the same level as chloroquine phosphate (Table 3).

Mefloquine hydrochloride was dose dependently bactericidal against all the test bacterial strains with a minimum inhibitory concentration (MIC) of $20 \mu \mathrm{g} / \mathrm{ml}$ except against the test host strains that had $\mathrm{R}$ plasmids and the MIC was $40 \mu \mathrm{g} / \mathrm{ml}$. The fluctuation mutagenicity tests were generally more sensitive than the plate incorporation method probably because of the greater diffusion of mefloquine molecules in liquid medium than in solid medium (Tables 1 and 2). Mutagenicity tests indicated that activation of mefloquine hydrochloride produced mutagenic products that mediated base-pair substitution mutation in the $E$. coli $\mathrm{WP}_{2}$ trp (pEB017) tester strains. The $S$. typhimurium his TA97 strains also mediated a weak frameshift mutation but mefloquine mutagenicity potential was most remarkable as a basepair substitutions mutagen.

\section{Discussion}

The effect of plasmid pEB017 in demonstrating enhanced induction of reversion of E. coli $\mathrm{WP}_{2}$ trp from $\mathrm{Trp}^{-}$to $\mathrm{Trp}^{+}$ compared to the enhanced reversion induction effect of the well known plasmid pKM101 in the isogenic E. coli $\mathrm{WP}_{2}$ trp indicated the superiority of pEB017 to pKM101 in E. coli host strains. It was also observed that there was a relative decreased number of revertants by higher concentration of mefloquine, thus indicating the toxicity of mefloquine hydrochloride (Table 2) hence induced revertants were obtained at 2.5 $\mu \mathrm{g} / \mathrm{ml}$ of mefloquine hydrochloride but not at $5.0 \mu \mathrm{g} / \mathrm{ml}$. It could therefore be suggested that compounds that are bactericidal and mutagenic have an optimum concentration that induced mutations, beyond the critical level, the bacterial tester strains reversion response and cell survival would be impaired. This phenomenon was earlier observed in nitrofurantoin and chlorpromazine hydrochloride mutagenicity ${ }^{15,20}$.

Our data also showed that the presence of $R$-mutator plasmids (pKM101 and pEB017) enhance detection of activated mefloquine as a base-pair mutagen. The positive response of the repair deficient tester strains, $\mathrm{WP}_{2}$ uvrA, without $R$-plasmids to activated mefloquine showed possible mediation of DNA damage repair enzymes in the observed base-pair mutagenic events. Generally, $W_{2}$ uvrA strains are sensitive determinanats of base-pair substitution mutagens ${ }^{3}$. The observed negative activity in $\mathrm{WP}_{2}$ strains could be attributed to nonpenetration or weak penetration of the bacterial cells by mefloquine. Possible facilitation of entry of the activated mefloquine into the bacterial tester strains are indicated by the positive response with activated mefloquine in the presence of mutator plasmids. 
JO Akerele \& EE Obaseiki-Ebor

Table 1: Revertant colonies in mefloquine reversion tests using the Plates Incorporation Tests Methods

\begin{tabular}{|c|c|c|c|c|}
\hline Organisms & $\begin{array}{c}\text { Negative } \\
\text { control plates }\end{array}$ & $\begin{array}{c}\text { Test plates } \\
\text { containing } 2.5 \mu \mathrm{g} \\
\text { mefloquine } / \mathrm{ml}\end{array}$ & $\begin{array}{l}\text { Positive control } \\
\text { plates }\end{array}$ & Significance \\
\hline E. coli $\mathrm{WP}_{2}$ trp & 3 & 2 & 500 & \\
\hline $\begin{array}{l}\text { E. coli } \mathrm{WP}_{2} \text { trp } \\
\text { (microsomal activation) }\end{array}$ & 2 & 2 & 480 & \\
\hline E. coli $\mathrm{WP}_{2}$ uvrA trp & 1 & 3 & 205 & \\
\hline $\begin{array}{l}\text { E. coli } \mathrm{WP}_{2} \text { uvrA trp } \\
\text { (microsomal activation) }\end{array}$ & 2 & 15 & 200 & $P<0.01$ \\
\hline E. coli $\mathrm{WP}_{2} \operatorname{trp}(\mathrm{pEB} 017)$ & 3 & 4 & 200 & \\
\hline $\begin{array}{l}\text { E. coli } \mathrm{WP}_{2} \text { trp (pEB017) } \\
\text { (microsomal activation) }\end{array}$ & 1 & 12 & 220 & $P<0.01$ \\
\hline E. coli WP 2 trp (pKM101) & 2 & 3 & 480 & \\
\hline $\begin{array}{l}\text { E. coli WP } 2 \text { trp (pKM101) } \\
\text { (microsomal activation) }\end{array}$ & 1 & 11 & 470 & $P<0.01$ \\
\hline S. tryphimurium his TA97 & 3 & 5 & 320 & \\
\hline $\begin{array}{l}\text { S. tryphimurium his TA97 } \\
\text { (microsomal activation) }\end{array}$ & 1 & 18 & 430 & $P<0.01$ \\
\hline
\end{tabular}

Table 2: Turbid tubes in Fluctuation test with mefloquine

\begin{tabular}{lcccc}
\hline \multicolumn{1}{c}{ Organisms } & $\begin{array}{c}\text { Positive control } \\
\text { per total tubes }\end{array}$ & $\begin{array}{c}\text { Negative control } \\
\text { per total tubes }\end{array}$ & $\begin{array}{c}50 \text { tubes containing } \\
\text { mefloquine } 5 \mu \mathrm{g} / \mathrm{ml}\end{array}$ & Significance \\
\hline E. coli $\mathrm{WP}_{2}$ trp & 50 & 2 & 2 & \\
$\begin{array}{l}\text { E. coli } \mathrm{WP}_{2} \text { trp } \\
\text { (microsomal activation) }\end{array}$ & 50 & 2 & 6 & $\mathrm{P}<0.01$ \\
$\begin{array}{l}\text { E. coli } \mathrm{WP}_{2} \text { uvrA trp } \\
\text { E. coli } \mathrm{WP}_{2} \text { uvrA trp }\end{array}$ & 50 & 0 & 1 & \\
(microsomal activation) & 50 & 1 & 7 & $\mathrm{P}<0.01$ \\
$\begin{array}{l}\text { E. coli } \mathrm{WP}_{2} \text { trp (pEB017) } \\
\text { E. coli } \mathrm{WP}_{2} \text { trp (pEB017) }\end{array}$ & 50 & 0 & 0 & \\
(microsomal activation) & 50 & 2 & 9 & $\mathrm{P}<0.01$ \\
E. coli $\mathrm{WP}_{2}$ trp (pKM101) & 50 & 3 & 1 & \\
$\begin{array}{l}\text { E. coli } \mathrm{WP}_{2} \text { trp (pKM101) } \\
\text { (microsomal activation) }\end{array}$ & 50 & 3 & 12 & $\mathrm{P}<0.01$ \\
S. tryphimurium his TA97 & 50 & 0 & 0 & \\
S. tryphimurium his TA97 \\
(microsomal activation)
\end{tabular}

The genotoxicity test indicated that mefloquine hydrochloride was not potentially genotoxic but concentration dependent cytotoxic. This could be seen in the inhibition of bacterial growth in wells at concentrations of $5 \mu \mathrm{g} / \mathrm{ml}$ whereas the other wells containing serial double dilutions supported bacterial growth. This observation agreed with the observed bactericidal action of 5 $\mu \mathrm{g} / \mathrm{ml}$ mefloquine hydrochloride in the plate incorporation mutagenicity test. This study therefore corroborates the earlier report of 


\section{JO Akerele \& EE Obaseiki-Ebor}

Davidson et al. ${ }^{21}$ that mefloquine weakly binds to DNA. The genotoxicity potentials of mefloquine favourably compared with the negative control (without the test or positive compounds) that contained only the growth medium. PFU/plate obtained from the mefloquine wells contrasted with the positive control wells containing nalidixic acid and 2nitrofluorene (Table 3 ), thus indicating that mefloquine hydrochloride was not genotoxic. Considering the earlier results of Schupbach $^{22}$ that indicated mefloquine to be non-mutagenic in the now obsolete tester strains, the results of this study constitute an instance where the use of an improved tester strain (i.e., containing a novel mutator plasmid $^{9}$ ) and/or the use of a particular species of bacterial tester strain enabled the detection of a compound as a mutagen that was earlier documented to be nonmutagenic. Since mefloquine hydrochloride exhibits base-pair substitution mutagenesis and is not strictly genotoxic, and remains a very effective therapeutic antimalarial agent, its use as a last line antimalarial agent should still be encouraged.

Table 3: Induction of prophage lambda by mefloquine hydrochloride, nalidixic acid and 2nitrofluorene

\begin{tabular}{|c|c|c|c|}
\hline & $\begin{array}{l}\text { Sample } \\
\text { Well A }\end{array}$ & $\begin{array}{l}\text { Sample } \\
\text { Well B }\end{array}$ & $\begin{array}{l}\text { Sample } \\
\text { Well B }\end{array}$ \\
\hline $\begin{array}{l}\text { Control (no } \\
\text { chemical) }\end{array}$ & 1 & 1 & 1 \\
\hline $\begin{array}{l}\text { Mefloquine } \\
\text { hydrochloride }\end{array}$ & 2.1 & 1.5 & 1.1 \\
\hline $\begin{array}{l}\text { Mefloquine } \\
\text { hydrochloride } \\
\text { (microsomal } \\
\text { activation }\end{array}$ & 2.5 & 1.5 & 1.1 \\
\hline $\begin{array}{l}\text { Chloroquine } \\
\text { phosphate }\end{array}$ & 2.5 & 1.5 & 1.0 \\
\hline Nalidixic acid & 5.5 & 6.4 & 5.9 \\
\hline 2-nitrofluorene & 5.8 & 8.8 & 7.5 \\
\hline \multicolumn{4}{|c|}{$\begin{array}{l}\text { Values indicate the ratio of proportion of } \\
\text { PFU/plate in the control (no chemical) to the tes } \\
\text { compound (mefloquine hydrochloride) and the } \\
\text { positive controls - nalidixic acid and } \\
\text { nitrofluorene }\end{array}$} \\
\hline
\end{tabular}

\section{Acknowledgements}

The authors are grateful to Professor S.A. Adelusi (Department of Pharmaceutical Chemistry, University of Benin, Benin City, Nigeria) for generously providing the mefloquine hydrochloride powder obtained from Walter Reed Army Institute of Research, Washington, D.C., USA. Also we are grateful to Professor Bruce Ames, University of California, Berkely Campus, California for providing the Salmonella tryphimurium TA97 tester strain and Professor Rossman, Institute of Environmental Medicine, New York, for providing the $E$. coli strains $W_{2} \mathrm{~S}$ (lambda) $\mathrm{F}^{-}$and TA-008 for the genotoxicity tests. The financial support from the International Foundation for Science-Grant No. F/1019-2 given to EEO for this study is gratefully acknowledged.

\section{References}

1. McCann J. Choi E, Yamasaki E, Ames BN.. Detection of carcinogens as mutagens in the Salmonella/microsome test: assay of 300 chemicals. Proc Natl Acad Sci (Wash) 1975; 72: 5135-9.

2. Ames BN, McCann J, Yamasaki E. Methods of detecting carcinogens and mutagens with the Salmonella/mammalian-microsome mutagenicity test. Mutation Res 1975; 31: 347-64.

3. Levin DE, Yamasaki E, Ames BN. A new Salmonella tester strain TA97, for the detection of frameshift mutagens. A run of cytosines as a mutational hot-spot. Mutation Res 1982; 94: 315-30.

4. Maron DM, Ames BN. Revised methods for Salmonella mutagenicity test. Mutation Res. 1983; 113: 173-215.

5. Green MHL, Muriel WJ. Mutagen testing using trp ${ }^{+}$ reversion in E. coli. Mutation Res. 1976; 38: 332.

6. Green MHL. Mutagen testing trp reversion in Escherichia coli: Handbook of mutagenicity test procedures, $2^{\text {nd }}$ ed. Elesevier Science Publishers, 1984

7. McCann J, Spingarn NE, Kobori J, Ames BN. Detection of carcinogens are mutagens: bacterial tester strains with R-factor plasmids. Proc Natl Acad Sci (Wash.) 1975; 72: 979-83.

8. Obaseiki-Ebor EE, Akerele JO. Nitrofuran Mutagenicity: Induction of frameshift mutation. Mutation Res 1986; 175: 149-152.

9. Obaseiki-Ebor EE, Smith KC. Properties of Rplasmid pEBO107, which confers both enhanced UV-radiation resistance and mutability

Trop J Pharm Res, December 2002; 1 (2) 


\section{JO Akerele \& EE Obaseiki-Ebor}

to wild-type recA and umuC strains of Escherichia coli K12. Mutation Research 1991; 267: 67-76.

10. Houk VS, DeMarini DM. Induction of prophage lambda by chlorinated pesticides. Mutation Res 1987; 182: 193 - 201.

11. DeMarini DM, Brooks HG, Parkes DG. Induction of Prophage lambda by Chlorophenols. Environmental and Molecular Mutagenesis 1990; 15: 1-19.

12. Moreau $P$, Bailore $A$, Devoret $R$. Prophage lambda induction in $E$. coli $\mathrm{K} 12$ envA uvrB: A highly sensitive test for potential carcinogens. Proc Natl Acad Sci USA 1976; 3(10): 3700-4.

13. Obaseiki-Ebor EE, Obasi EE. Aspects of chloroquine mutagenicity. Mutation Res 1986; 175: $51-9$.

14. Davis BD, Mingioli ES. Mutants of $E$. coli requiring methionine or vitamin $B_{12}$. J Bactriol. 1950; 10: 17-28.

15. Obaseiki-Ebor, EE, Akerele JO. The mutagenic activity of chlorpromazine. Mutation Res. 1988; 208: 33-8.

16. Lowry $\mathrm{OH}$, Rosebrough NJ, Farr A, Randall RJ. Protein measurement with the folin-phenol reagent. J Biol Chem 1951; 193.
17. Brusick DJ, Simmon VF, Rosenkraz HS, Ray VA Stafford RS. An evaluation of the E. coli $\mathrm{WP}_{2}$ reverse mutation assay. Mutation Res 1980; 76: 169-90.

18. Green MHL, Muriel WJ, Bridges BA. Use of a simplified fluctuation test to detect low levels of mutagens. Mutation Res 1976; 38: 33-42.

19. Houk VS, DeMarini DM. Use of the microscreen phage-induction assay to access the genotoxicity of 14 hazardous industrial wastes. Environ Molecular Mutagen 1988; 11: 13-29.

20. Obaseiki-Ebor EE, Akerele JO. Expression of a novel R-plasmid pEB017 compared to pKM101 in $E$. coli wild-type, recA and uvrA strains. Mutation Res 1986; 192: 172-80.

21. Davidson MW, Griggs Jr BG, Boykin DW, Wilson WD. Mefloquine, a clinically useful quinolinemethanol anti-malarial which does not significantly bind to DNA. Nature (London) 1975; 254: 632-4.

22. Schupbach ME. Mutagenicity evaluation of the two anti-malarial agents, chloroquine and mefloquine using a bacterial fluctuation test. Mutation Res 1979; 68: 41-9. 